\title{
ISOLATION AND PHYSICO-CHEMICAL CHARACTERIZATION OF LIGNINS FROM ULTRASOUND IRRADIATED FAST-GROWING POPLAR WOOD
}

\author{
Tong-Qi Yuan, ${ }^{\mathrm{a}}$ Shaoni Sun, ${ }^{\mathrm{a}}$ Feng Xu, ${ }^{\mathrm{a}, *}$ and Run-Cang Sun ${ }^{\mathrm{a}, \mathrm{b}, *}$
}

Ultrasonic irradiation with organic solvents and alkaline extractions were carried out on a fast-growing poplar wood, triploid of Populus tomentosa Carr., in an attempt to develop efficient lignin isolation procedures. Four organosolv and three alkaline lignin fractions were successively isolated and comparatively characterized by sugar analysis, alkaline nitrobenzene oxidation, gel permeation chromatography (GPC), Fourier transform infra-red spectroscopy (FT-IR), quantitative ${ }^{13} \mathrm{C}$, and $2 \mathrm{D}$ HSQC nuclear magnetic resonance (NMR) spectroscopy, as well as thermogravimetric analysis (TGA). The results showed that the ultrasonic treatments and sequential extractions with three different concentrations of $\mathrm{NaOH}$ led to a release of $90.9 \%$ of the original lignin. The four organosolv lignin preparations obtained under the ultrasound-assisted extractions were degraded significantly and contained more carbohydrate and non-condensed syringyl units when compared to the three alkaline lignin preparations. Furthermore, the analyses confirmed that $L_{5}$, the lignin preparation with the highest yield (44.6\% of the original lignin), was partially acylated at the $\mathrm{Y}$-carbon of the side-chain preferentially over syringyl units. The percentage of lignin acylation of $\beta-O-4$ ' linkages was about $14 \%$. The amount of $\beta-O-4, \beta-\beta$, and $-\mathrm{OCH}_{3}$ were estimated to be about $0.31 / \mathrm{Ar}, 0.06 / \mathrm{Ar}$, and 1.73/Ar, respectively. The ratio of $\mathrm{S} / \mathrm{G}$ was calculated to be 2.0 .

Keywords: HSQC; Lignin; Poplar wood; Quantitative ${ }^{13}$ C NMR; Ultrasound

Contact information: a: Institute of Biomass Chemistry and Technology, Beijing Forestry University, 100083,Beijing, China; b: State Key Laboratory of Pulp and Paper Engineering, South China University of Technology, 510640, Guangzhou, China; *Corresponding author:xfx315@bjfu.edu.cn (F.Xu),

rcsun3@bjfu.edu.cn (R.C.Sun)

\section{INTRODUCTION}

In order to improve the ability to meet the increasing demand for paper and cardboard, the cultivation of fast-growing forestry is now the subject of accelerating interest and awareness. The use of poplar wood for the production of paper and paperboard is increasing at a significant rate, especially in the more temperate regions (Bose et al. 2009). For instance, the National Development and Reform Commission of China promulgated the National Forestry-Paper Integration Project Construction "15" and the 2010 Specific Plan in 2004 (http://wwwold.sdpc.gov.cn/1/1200402251.htm). In this project, fast-growing poplar wood plays a very important role because of its high pest resistance, high survival rate, high quality, and short rotation length. Besides, due to increasing environmental concerns, high oil prices, and the instability/uncertainty of petroleum reserves, there is a growing need to find alternatives to crude oil as the primary 
feed stock for the chemicals and fuel industries. Ethanol has been demonstrated to be a viable alternative (Rostrup-Nielsen 2005; Ragauskas et al. 2006; Himmel et al. 2007; Kunkes et al. 2008), and meanwhile poplar has been considered to be a potential biorefinery feedstock for ethanol production (Davison et al. 2006; Balan et al. 2009).

Unfortunately, lignin, a major component of the cell wall of vascular plants, has long been recognized for its negative impact on papermaking and bioethanol production (Li et al. 2008). Generally, lignin is considered as being formed by the dehydrogenative polymerization of three $p$-hydroxycinnamyl alcohol precursors: $p$-coumaryl, coniferyl, and sinapyl alcohols (Higuchi 1997). Each of these monolignols gives rise to a different type of lignin unit called $\mathrm{H}$ ( $p$-hydroxyphenyl), $\mathrm{G}$ (guaiacyl), and $\mathrm{S}$ (syringyl) units, respectively. However, it is now widely accepted that other monomers also participate in coupling reactions that give rise to the lignin macromolecule, such as p-hydroxycinnamaldehydes, ferulic acid, or 5-hydroxyconiferyl alcohol (Ralph 2007; Vanholme et al. 2008). Furthermore, lignin is a network polymer, which has many kinds of linkages between units, such as $\beta-O-4^{\prime}, \beta-\beta, \beta-5^{\prime}, 5-5^{\prime}$, and $4-O-5^{\prime}$ linkages. The S:G ratio of hardwood lignin has long been identified as a significant parameter in delignification processes, and more recent results have shown that it is also important in determining the amount of ethanol that can be obtained from fermentation of hydrolyzed wood (Govender et al. 2009). The rate of kraft delignification is believed to be enhanced by a high S:G ratio. The lower the lignin content and the proportion of condensed structures in lignin, the less energy and reagents consumption are needed for the chemical pulping and bleaching processes. Moreover, the presence of lignin in plant cell walls impedes the breakdown of cell wall polysaccharides to simple sugars and the subsequent conversion of these sugars to usable fuel (Weng et al. 2008). Currently, the major by-product of the bioconversion of lignocellulosic resources to ethanol and in the industrial production of paper is lignin, which at present is considered predominantly for use as a process fuel. However, because of its polyphenolic chemical structure, lignin can be used in a variety of nonspecific and novel applications (Yuan et al. 2009). For instance, lignin can be depolymerized into liquid bio-oil, which is suitable as a blending component to be combined with conventional fossil fuels for motor fuel applications (Kleinert and Barth 2008). It is obvious that conversion of this low-value by-product into high-value co-products will help to offset the costs of both papermaking and bioethanol production.

The mechanochemical effect of ultrasound is believed to accelerate the extraction of organic compounds from plant materials due to disruption of cell walls and enhanced mass transfer of the cell contents (EI'Piner 1964). Recently, sonication has been reported to extract phenolic compounds from coconut (Cocos nucifera) shell (Rodrigues et al. 2008) and wheat bran (Wang et al. 2008), and xyloglucan from apple pomace (Fu et al. 2006). Different polysaccharides were successively extracted from ultrasonically irradiated Salvia officinalis L., corn bran, buckwheat hulls, and the roots of valerian (Valeriana officinalis L.) (Hromádková et al. 1999; Ebringerová and Hromádková 2002; Hromádková et al. 2002; Hromádková and Ebringerová 2003). In the present study, to explore an efficient method to isolate lignin, ultrasound-irradiated organic solvents and alkali extractions were carried out on a fast-growing poplar wood, one of the primary lignocellulosic feedstock being investigated for the production of ethanol and paper (Ballesteros et al. 2004; Yang et al. 2006). The structural features and physico-chemical 
properties of the fractionated lignins were thoroughly investigated with a view to obtain valuable information for the industries of papermaking, bioethanol production, and value-added utilization of lignin.

\section{EXPERIMENTAL}

\section{Materials}

Triploid Populus tomentosa Carr., a fast-growing poplar tree, 7 years old, was harvested from the experimental farm of Beijing Forestry University. Poplar is known to consist mainly of three groups of organic compounds - cellulose $(41.8 \%)$, hemicelluloses (32.3\%), and lignin (21.5\%) - on a dry weight basis (Yuan et al. 2010). The outer and inner layers of bark were peeled off, and the wood was cut into small pieces and then dried at $60{ }^{\circ} \mathrm{C}$ in an oven for $16 \mathrm{~h}$. The wood sample was then ground to pass through a $0.8 \mathrm{~mm}$ size screen. The material, which passed through a 60-mesh screen and was retained on a 100-mesh screen, was collected for subsequent experimentation.

\section{Isolation of Lignin}

A scheme for ultrasound-assisted organic solvents and alkaline solutions extraction of lignin is shown in Fig. 1. The dried sample was first extracted with toluene-ethanol $(2: 1, \mathrm{v} / \mathrm{v})$ in a Soxhlet apparatus for $6 \mathrm{~h}$. The dewaxed material $(14 \mathrm{~g})$ was then soaked in $95 \%$ ethanol with a $1: 15$ material to liquor ratio $(\mathrm{g} / \mathrm{ml})$. The mixture was treated with ultrasound at $25{ }^{\circ} \mathrm{C}$ for $30 \mathrm{~min}$ in a $500 \mathrm{~mL}$ beaker using the Sonic system Scientz-IID (NingBo, 20-24 kHz) provided with a horn at a sonic power of $570 \mathrm{~W}$. To avoid any chemical modification introduced by the increasing temperature during the ultrasonic treatment, the beaker was placed in a water bath, which could control the temperature at around $25{ }^{\circ} \mathrm{C}$. After filtration, the residue was washed thoroughly with $95 \%$ ethanol and then dried in an oven at $60{ }^{\circ} \mathrm{C}$ for $16 \mathrm{~h}$. The filtrate was collected and concentrated at reduced pressure for isolation of solubilized lignin. This lignin fraction was named $\mathrm{L}_{1}$. The residue was successively treated with methanol, dioxane, and dimethyl sulfoxide under the same conditions. It should be noted that during ultrasound-assisted extraction with dimethylsulfoxide, the filtrate was first concentrated at reduced pressure and then precipitated in 3 volumes of $95 \%$ ethanol. A pellet rich in hemicelluloses was recovered by filtering, washing with $70 \%$ ethanol, and freeze-drying. After evaporation of ethanol, the dimethyl sulfoxide-soluble lignin was obtained by precipitation at $\mathrm{pH} 1.5$ to 2 , which was adjusted by $6 \mathrm{M} \mathrm{HCl}$. These three organosolv lignin fractions were named $\mathrm{L}_{2}, \mathrm{~L}_{3}$, and $\mathrm{L}_{4}$, respectively. After these steps, the ultrasound-pretreated material was successively extracted with $70 \%$ ethanol containing $1 \%$ $\mathrm{NaOH}, 3 \% \mathrm{NaOH}$, and $6 \% \mathrm{NaOH}$ at $75{ }^{\circ} \mathrm{C}$ for $3 \mathrm{~h}$. In each step, the residue was filtered off in a Büchner funnel and washed with distilled water until the filtrate was neutral and then dried in an oven at $60{ }^{\circ} \mathrm{C}$ for $16 \mathrm{~h}$. Each of the supernatant fluids was neutralized to $\mathrm{pH} 5.5$ with $6 \mathrm{M} \mathrm{HCl}$, and the solubilized hemicelluloses were isolated by precipitation of the concentrated filtrates with 3 volumes of $95 \%$ ethanol. The acid-insoluble lignin preparations were obtained by the same method as precipitation of dimethyl sulfoxide-soluble lignin except for washing with acidified water ( $\mathrm{pH}$ 2.0) before freeze-drying. Accordingly these three alkaline liginin fractions were titled $\mathrm{L}_{5}, \mathrm{~L}_{6}$, and $\mathrm{L}_{7}$, respectively. 


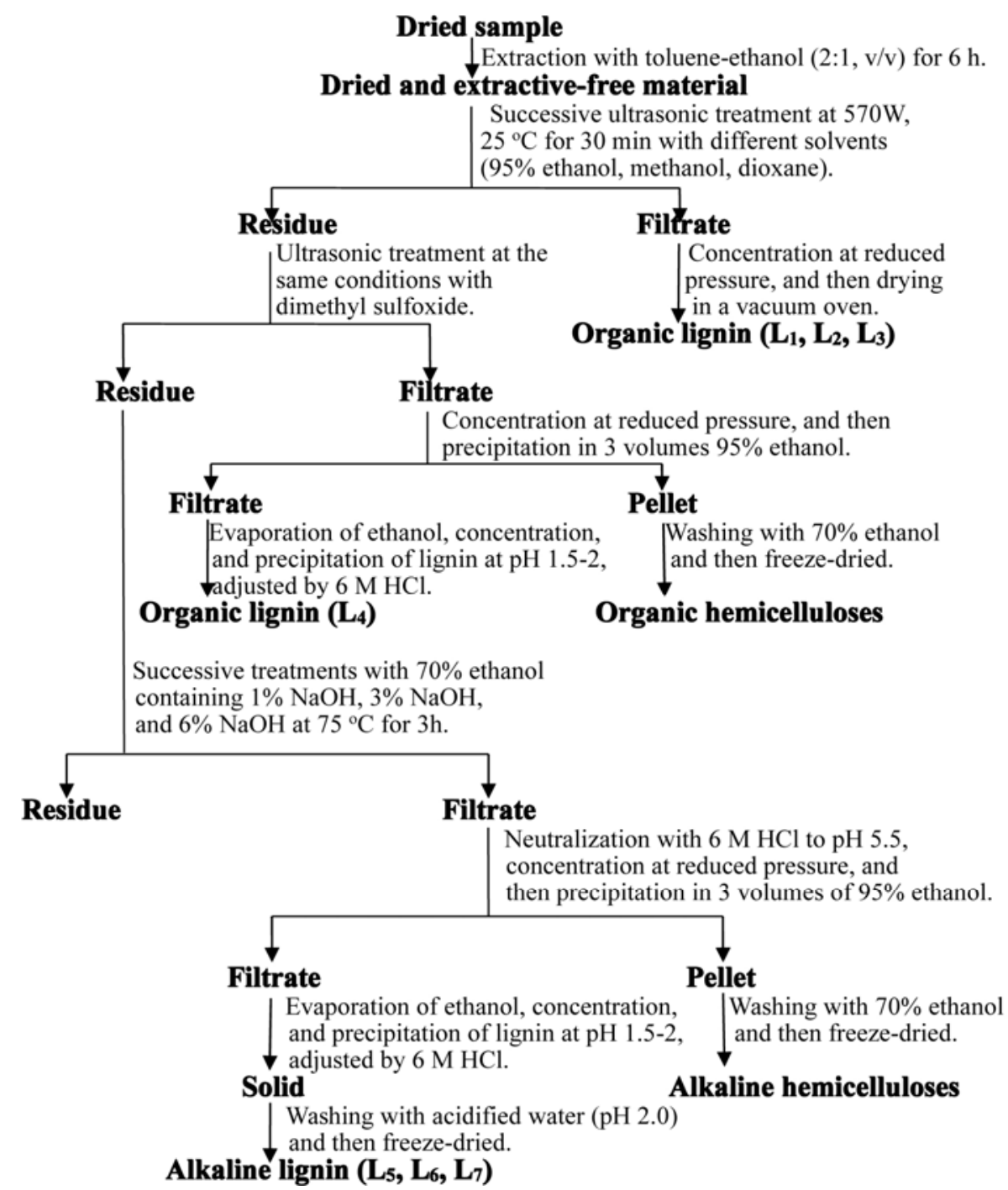

Fig. 1. Scheme for extraction of ultrasound-assisted organosolv and alkaline lignins

\section{Analytical Methods}

The carbohydrate moieties associated with the seven lignin preparations were determined by hydrolysis with dilute sulfuric acid according to the procedure described in a previous report (Yuan et al. 2010). After hydrolysis, the mixture was filtered and diluted 50-fold, and analyzed by a high-performance anion-exchange chromatography (HPAEC) system (Dionex ICS3000, U.S.) with pulsed amperometric detector, AS50 autosampler, the CarbopacTM PA-20 column $(4 \times 250 \mathrm{~mm}$, Dionex), and the guard PA-20 column (3 $\times 30 \mathrm{~mm}$, Dionex). The analysis of sugar composition in the present study was run in duplicate, and average values were calculated for all seven lignin preparations.

The monomeric composition of the non-condensed monomeric units of the lignin preparations was characterized by alkaline nitrobenzene oxidation and analyzed for the resulting aromatic aldehydes and acids by high-performance liquid chromatography (HPLC), as previously reported (Yuan et al. 2009). One change was that in the present 
study alkaline nitrobenzene oxidation of the seven lignin preparations was carried out at $170{ }^{\circ} \mathrm{C}$ for $3 \mathrm{~h}$ in a sealed Teflon-lined autoclave. The analysis of the resulting aromatic aldehydes and acids was run in duplicate, and average values were calculated for all seven lignin preparations.

The weight-average $\left(M_{\mathrm{w}}\right)$ and number-average $\left(M_{\mathrm{n}}\right)$ molecular weights of the lignin preparations were determined by gel permeation chromatography (GPC) on a PL-gel $10 \mathrm{~mm}$ Mixed-B $7.5 \mathrm{~mm}$ ID column. A $4 \mathrm{mg}$ sample was dissolved in $2 \mathrm{~mL}$ of tetrahydrofuran, and a $10 \mu \mathrm{L}$ sample in solution was injected. The column was operated at ambient temperature and eluted with tetrahydrofuran at a flow rate of $1 \mathrm{~mL} / \mathrm{min}$. Monodisperse polystyrene was used as the standard for the molecular weight of lignin.

The FTIR spectra of the lignin preparations were recorded from a $\mathrm{KBr}$ disc containing 1\% finely ground samples on a Tensor 27 FTIR spectrophotometer in the range of 4000 to $400 \mathrm{~cm}^{-1}$. Thirty-two scans were taken for each sample with a resolution of $2 \mathrm{~cm}^{-1}$ in the transmission mode.

The NMR spectra were recorded at $25^{\circ} \mathrm{C}$ on a Bruker AVIII $400 \mathrm{MHz}$ spectrometer. The lignin sample $\left(180 \mathrm{mg}\right.$ for $\left.{ }^{13} \mathrm{C}\right)$ was dissolved in $1 \mathrm{~mL} \mathrm{DMSO}-d_{6}(99.8 \% \mathrm{D})$. The quantitative ${ }^{13} \mathrm{C}$ NMR spectrum was recorded in the FT mode at $100.6 \mathrm{MHz}$. The inverse gated decoupling sequence, which allows quantitative analysis and comparison of signal intensities, was used with the following parameters: $30^{\circ}$ pulse angle; 2 s relaxation delay; 64K data points, and 30000 scans. The central solvent (DMSO) peak was used as an internal chemical shift reference point $\left(\delta_{\mathrm{C}} 39.5 ; \delta_{\mathrm{H}} 2.49 \mathrm{ppm}\right)$.

Two-dimensional NMR spectra were recorded at $25{ }^{\circ} \mathrm{C}$ on a Bruker AVIII 400 $\mathrm{MHz}$ spectrometer. About $90 \mathrm{mg}$ of lignin was dissolved in $0.5 \mathrm{~mL}$ of DMSO- $d_{6}(99.8 \%$ D). 2D-NMR spectra were recorded in HSQC experiments. The spectral widths were $5000 \mathrm{~Hz}$ and $20000 \mathrm{~Hz}$ for the ${ }^{1} \mathrm{H}$ - and ${ }^{13} \mathrm{C}$-dimensions, respectively. The number of collected complex points was 1024 for ${ }^{1} \mathrm{H}$-dimension with a recycle delay of $1.5 \mathrm{~s}$. The number of transients was 64, and 256 time increments were always recorded in the ${ }^{13} \mathrm{C}$-dimension. The ${ }^{1} J_{\mathrm{CH}}$ used was $145 \mathrm{~Hz}$. Prior to Fourier transformation, the data matrixes were zero filled up to 1024 points in the ${ }^{13} \mathrm{C}$-dimension. Data processing was performed using standard Bruker Topspin-NMR software. HSQC cross-signals were assigned by combining the results of the different experiments and comparison with the literature (del Río et al. 2008; Lu and Ralph 2003; Lu et al. 2004; Martínez et al. 2008; del Río et al. 2009; Rencoret et al. 2009; Villaverde et al. 2009). A semiquantitative analysis of the intensities of the HSQC cross-signal was performed according to the method given in previous reports (del Río et al. 2008, 2009; Villaverde et al. 2009). In the aliphatic oxygenated region, the relative abundance of the different inter-unit linkages were estimated from $\mathrm{C}_{\alpha}-\mathrm{H}_{\alpha}$ correlations to avoid possible interference from homonuclear ${ }^{1} \mathrm{H}-{ }^{1} \mathrm{H}$ couplings, and the relative abundance of side-chains involved in the different interunit linkages were calculated. In the aromatic region, $\mathrm{C}_{2,6}-\mathrm{H}_{2,6}$ correlations from $\mathrm{S}$ units and $\mathrm{C}_{2}-\mathrm{H}_{2}$ correlation from $\mathrm{G}$ units were used to estimate the $\mathrm{S} / \mathrm{G}$ ratio of lignin.

Thermal stability determinations of the lignin preparations were performed using thermogravimetric analysis (TGA) (DTG-60, Shimadzu, Japan). Samples of approximately $10 \mathrm{mg}$ weight were heated in an aluminum crucible to $600{ }^{\circ} \mathrm{C}$ at a heating rate of $10{ }^{\circ} \mathrm{C} / \mathrm{min}$ while the apparatus was continually flushed with a nitrogen flow of $20 \mathrm{ml} / \mathrm{min}$. Prior to evaluation, all the samples were oven-dried at $105^{\circ} \mathrm{C}$ for $2 \mathrm{~h}$. 


\section{RESULTS AND DISCUSSION}

\section{Yield and Purity}

In the present experiments, the dewaxed material was first partially delignified under successive ultrasonic treatments at $570 \mathrm{~W}, 25{ }^{\circ} \mathrm{C}$ for $30 \mathrm{~min}$ with $95 \%$ ethanol, methanol, dioxane, and dimethyl sulfoxide. The yield of lignin ( $\%$ original lignin) extracted by sonication with organic solvents and alkaline solutions is given in Table 1 . It must be mentioned that calibration of the yield of lignin has been carried out based on the results of sugar analysis. During these processes a total of about $34.1 \%$ of the original lignin was extracted with the four organic solvents used in succession. This data suggest that, under the ultrasonic treatments given, some linkages between lignin and polysaccharides were broken. It is known that during the alkaline treatment of the dewaxed and partially delignified fast-growing poplar wood, some alkali-labile linkages between lignin molecules, or between lignin and polysaccharides, might be broken by alkali. Acidic moieties such as carboxylic or phenolic groups, ionized in the alkaline solution, might also promote the solubilization of the hemicelluloses and residual lignin, either by increasing the solubility of individual fragments or by inducing the swelling of the cell wall (Scalbert et al. 1986). Therefore, after these steps, the ultrasonically pretreated material was successively extracted with $70 \%$ ethanol containing $1 \% \mathrm{NaOH}, 3 \% \mathrm{NaOH}$, and $6 \% \mathrm{NaOH}$ at $75{ }^{\circ} \mathrm{C}$ for $3 \mathrm{~h}$, and $44.6 \%, 9.8 \%$, and $2.4 \%$ of the original lignin were obtained, respectively. In summary, in the present experiments, $90.9 \%$ of the original lignin could be extracted from the fast-growing poplar wood.

Table 1. Yield of Lignin (\% Original Lignin) Released in the Treatment of Ultrasonic Irradiation with Organic Solvents and Alkaline Solutions

\begin{tabular}{|l|l|l|l|l|l|l|l|}
\hline Lignin Preparation $^{\mathrm{a}}$ & \multicolumn{4}{|c|}{ Organosolv Lignin } & \multicolumn{4}{c|}{ Alkaline Lignin } \\
\cline { 2 - 9 } & $\mathrm{L}_{1}$ & $\mathrm{~L}_{2}$ & $\mathrm{~L}_{3}$ & $\mathrm{~L}_{4}$ & $\mathrm{~L}_{5}$ & $\mathrm{~L}_{6}$ & $\mathrm{~L}_{7}$ \\
\hline Yield & 14.4 & 5.8 & 2.3 & 11.6 & 44.6 & 9.8 & 2.4 \\
\hline Total & 34.1 & \multicolumn{4}{|c|}{56.8} \\
\hline
\end{tabular}

a Corresponding to the lignin preparations in Fig. 1.

To characterize composition of the ultrasound-assisted organic solvents and alkaline solutions extracted lignin, the seven lignin preparations were prepared for determination of their carbohydrate content, and the results are given in Table 2. As can be seen, all seven lignin preparations contained associated carbohydrate. In the four organosolv lignin preparations, the carbohydrate associated with the lignin preparations amounted to $13.11 \%, 13.15 \%, 4.62 \%$, and $12.11 \%$, respectively. The lignin preparation $\mathrm{L}_{3}$, which was extracted with dioxane under the given experimental conditions, contained the lowest carbohydrate among the four organosolv lignins. However, it should be noted that glucose amounted to a great proportion of the sugar and uronic acids, from $48.4 \%$ to $89.8 \%$. These data indicated that cellulose was the main component of the carbohydrate associated with the lignin preparations. Therefore, the results suggest that the macromolecules of cellulose in the cell walls might be degraded during the treatments by ultrasonic irradiation with organic solvents under the conditions given. Besides, the high proportion of glucose in the sugar analysis of the four organosolv lignin preparations may also be attributed to the incorporation of xyloglucan. On the contrary, the data showed 
that the three alkaline lignin preparations contained relatively low amounts of associated carbohydrate, in which hemicelluloses were the main component. In comparison of the associated hemicelluloses in the three alkaline lignin preparations $\mathrm{L}_{5}-\mathrm{L}_{7}$, it was clear to note that an increase in the concentration of $\mathrm{NaOH}$ from $1 \%$ to $3 \%$, and to $6 \%$ resulted in a decrease in the hemicelluloses content from $1.21 \%$ to $0.50 \%$, and to $0.19 \%$, respectively. This phenomenon revealed that more $\alpha$-ether linkages between lignin and hemicelluloses would be cleaved during the successive extractions with an increasing of the concentration of $\mathrm{NaOH}$. This was in line with the results of Sun et al. (2000) when studying the purity of lignin extracted from fast-growing poplar wood by an increase in the concentration of $\mathrm{NaOH}$.

Table 2. The Content of Neutral Sugars and Uronic Acids (\% Dry Sample, W/W) in the Isolated Lignin Preparations

\begin{tabular}{|l|l|l|l|l|l|l|l|}
\hline Sugar/Uronic acids & \multicolumn{7}{|c|}{ Lignin Preparation $^{\text {a }}$} \\
\hline & $\mathrm{L}_{1}$ & $\mathrm{~L}_{2}$ & $\mathrm{~L}_{3}$ & $\mathrm{~L}_{4}$ & $\mathrm{~L}_{5}$ & $\mathrm{~L}_{6}$ & $\mathrm{~L}_{7}$ \\
\hline Rhamnose & 0.10 & 0.19 & 0.05 & 0.39 & 0.08 & 0.02 & $\mathrm{ND}^{\mathrm{b}}$ \\
\hline Arabinose & 0.10 & 0.35 & 0.10 & 2.12 & 0.46 & 0.13 & 0.06 \\
\hline Galactose & 0.64 & 1.47 & 0.18 & 1.51 & 0.16 & 0.05 & 0.03 \\
\hline Glucose & 11.78 & 10.38 & 4.08 & 5.86 & 0.17 & 0.06 & 0.04 \\
\hline Mannose & 0.03 & 0.35 & 0.01 & 1.29 & $\mathrm{ND}$ & $\mathrm{ND}$ & $\mathrm{ND}$ \\
\hline Xylose & 0.06 & 0.14 & 0.07 & 0.58 & 0.10 & 0.24 & 0.06 \\
\hline Uronic acids & 0.40 & 0.27 & 0.13 & 0.36 & 0.24 & $\mathrm{ND}$ & $\mathrm{ND}$ \\
\hline Total & 13.11 & 13.15 & 4.62 & 12.11 & 1.21 & 0.50 & 0.19 \\
\hline
\end{tabular}

${ }^{\mathrm{a}}$ Corresponding to the lignin preparations in Fig. 1.

${ }^{\mathrm{b}} \mathrm{ND}=$ not detectable.

\section{Content of Phenolic Acid and Aldehydes}

Among the methods to deduce their structural features and degree of condensation of protolignin as well as isolated lignins, alkaline nitrobenzene oxidation of lignins is a simple but by no means perfect method for the characterization of lignins. However, this method is a useful approach in combination with other characterization methods, such as FTIR and NMR spectroscopy. Therefore, in the present study alkaline nitrobenzene oxidation was applied to determine whether a significant structural difference exists between these lignin fractions. Table 3 shows the relative yields of phenolic acids and aldehydes in each of the lignin preparations. As can be seen from Table 3, the predominant oxidation products were found to be vanillin, syringic acid, and syringaldehyde, which together comprised 60.0 to $81.7 \%$ of the total nitrobenzene oxidation products and resulted from the degradation of non-condensed guaiacyl units and non-condensed syringyl units. However, it is interesting to note that the relative yields of $p$-hydroxybenzaldehyde $(8.1$ to $32.1 \%)$ and $p$-hydroxybenzonic acid (1.2 to $6.0 \%$ ) were higher when compared to the results of alkaline nitrobenzene oxidation of alkaline lignin preparations studied by Sun et al (2000). This phenomenon might be interpreted as being due to the incorporation of non-condensed $p$-hydroxyphenyl units into the lignin or $p$-coumaric acid ester linked to it. Both of these moieties are oxidized to $p$-hydroxybenzaldehyde at high yields during the alkaline nitrobenzene oxidation process. 
The incorporation of $p$-coumarate and $p$-hydroxyphenyl units was further confirmed by the NMR spectroscopy subsequently. This observation also indicated that treatments of fast-growing poplar wood with organic solvents under ultrasonic irradiation and alkaline solutions can only result in partial cleavage of these esterified linkages.

The $\mathrm{S}: \mathrm{G}$ ratio of hardwood lignin is a significant parameter in both delignification and fermentation of hydrolyzed wood processes. In the present study, the relative molar ratios of $S$ (the relatively total moles of syringaldehyde and syringic acid) to $G$ (the relatively total moles of vanillin and vanillic acid) appeared to be $2.5: 1$ in $\mathrm{L}_{1}, 1.5: 1$ in $\mathrm{L}_{2}$, 1.4:1 in $\mathrm{L}_{3}, 1.2: 1$ in $\mathrm{L}_{4}, 0.3: 1$ in $\mathrm{L}_{5}, 0.6: 1$ in $\mathrm{L}_{6}$, and $0.4: 1$ in $\mathrm{L}_{7}$. Recently, Bose et al. (2009) proposed a corrected nitrobenzene oxidation method to determine the S:G ratio of 13 poplars, and the values ranged from 1.01 to 1.68 . Therefore, it could be concluded that there were considerable structural variations among the seven lignin preparations. The four organosolv lignin preparations were dominated by non-condensed syringyl units, while the three alkaline lignin preparations were comprised of a large proportion of non-condensed guaiacyl units.

Table 3. The Yield (Relative Mol \%) of Phenolic Acids and Aldehydes from Alkaline Nitrobenzene Oxidation of the Lignin Preparations

\begin{tabular}{|l|c|c|c|c|c|c|c|}
\hline Phenolic Acids and Aldehydes & \multicolumn{7}{|c|}{ Lignin Preparation $^{\text {a }}$} \\
\hline & $\mathrm{L}_{1}$ & $\mathrm{~L}_{2}$ & $\mathrm{~L}_{3}$ & $\mathrm{~L}_{4}$ & $\mathrm{~L}_{5}$ & $\mathrm{~L}_{6}$ & $\mathrm{~L}_{7}$ \\
\hline$p$-Hydroxybenzonic Acid & 5.3 & 3.3 & 6.0 & 4.3 & 3.7 & 4.7 & 1.2 \\
\hline$p$-Hyroxybenzaldehyde & 23.2 & 17.4 & 32.1 & 11.3 & 8.1 & 12.1 & 14.9 \\
\hline Syringic Acid & 22.8 & 28.4 & 22.4 & 36.0 & 19.7 & 25.7 & 20.8 \\
\hline Syring Aldehyde & 28.2 & 19.7 & 13.3 & 9.9 & 2.7 & 4.4 & 2.9 \\
\hline Vanillic Acid & 3.7 & 3.4 & 1.8 & 4.9 & 6.5 & 9.4 & 7.0 \\
\hline Vanillin & 16.8 & 27.7 & 24.3 & 33.5 & 59.3 & 43.7 & 53.2 \\
\hline Mole Ratio of S/G & $2.5: 1$ & $1.5: 1$ & $1.4: 1$ & $1.2: 1$ & $0.3: 1$ & $0.6: 1$ & $0.4: 1$ \\
\hline
\end{tabular}

${ }^{a}$ Corresponding to the lignin preparations in Fig. 1.

${ }^{\mathrm{b}} \mathrm{S}$ represents the relatively total moles of syringaldehyde and syringic acid, $\mathrm{G}$ represents the relatively total moles of vanillin and vanillic acid.

\section{Molecular Weight Distribution}

The values of the weight-average $\left(M_{\mathrm{w}}\right)$ and number-average $\left(M_{\mathrm{n}}\right)$ molecular weights, calculated from the GPC curves (relative values related to polystyrene), and the polydispersity $\left(M_{\mathrm{w}} / M_{\mathrm{n}}\right)$ of the seven lignin preparations are given in Table 4 . It should be noted that tetrahydrofuran was used as eluant and all the seven lignin preparations were soluble in this solvent without derivatization. As shown in Table 4, all the seven lignin preparations exhibited low molecular-average weights, ranging from 910 to $2770 \mathrm{~g} / \mathrm{mol}$. In particular, the molecular-average weights of the four organosolv lignin preparations $(910$ to $1390 \mathrm{~g} / \mathrm{mol})$ were much lower than the three alkaline lignin preparations (2000 to $2770 \mathrm{~g} / \mathrm{mol}$ ). These molecular-average weights were rather lower when compared to the results obtained by Sun et al. (2000) (4520-6900 g/mol) during the study of extraction of lignins from fast-growing poplar wood with different concentrations of $\mathrm{NaOH}$. This obvious difference for the four organosolv lignin preparations was undoubtedly due to the effects of ultrasonic irradiation under the given conditions. The $\beta-O-4$ ' linkages between the lignin precursors under a relatively longer sonication period would be cleaved. 
Besides, we could note that the molecular-average weights of the alkaline lignin preparations in our previous studies were much higher than the alkaline lignin preparations obtained in the present study. One explanation for this phenomenon might be that the mechanochemical effect of ultrasound disrupted the cell walls and enhanced mass transfer of the cell contents (EI'Piner 1964). Therefore, the extraction of lignin from the ultrasonically pretreated material was easier than from that without ultrasonic pretreatment. Consequently, one could significantly avoid the condensation of lignin during the treatments at $75{ }^{\circ} \mathrm{C}$ for $3 \mathrm{~h}$ with an increase in the concentration of $\mathrm{NaOH}$. In addition, all the seven lignin preparations exhibited relatively narrow molecular weight distributions, as shown by $M_{\mathrm{w}} / M_{\mathrm{n}}<3$. The polydispersities of the four organosolv lignin preparations (1.63 to 1.90$)$ were lower than the three alkaline lignin preparations (2.18 to 2.92$)$. These data indicate that extraction of lignin under alkaline conditions led to the dissolution of lignin fractions with a broader molecular weight distribution when compared to the ultrasound-assisted organic solvents extraction in the present study.

Table 4. Weight-Average $\left(M_{\mathrm{w}}\right)$ and Number-Average $\left(M_{\mathrm{n}}\right)$ Molecular Weights and Polydispersity $\left(M_{\mathrm{w}} / M_{\mathrm{n}}\right)$ of the Isolated Lignin Preparations

\begin{tabular}{|l|l|l|l|l|l|l|l|}
\hline & \multicolumn{6}{l}{ Lignin Preparation $^{\mathrm{a}}$} \\
\cline { 2 - 8 } & $\mathrm{L}_{1}$ & $\mathrm{~L}_{2}$ & $\mathrm{~L}_{3}$ & $\mathrm{~L}_{4}$ & $\mathrm{~L}_{5}$ & $\mathrm{~L}_{6}$ & $\mathrm{~L}_{7}$ \\
\hline$M_{\mathrm{w}}$ & 910 & 960 & 1390 & 1030 & 2000 & 2770 & 2310 \\
\hline$M_{\mathrm{n}}$ & 560 & 570 & 730 & 620 & 690 & 950 & 1060 \\
\hline$M_{\mathrm{w}} M_{\mathrm{n}}$ & 1.63 & 1.68 & 1.90 & 1.66 & 2.90 & 2.92 & 2.18 \\
\hline
\end{tabular}

${ }^{\text {a }}$ Corresponding to the lignin preparations in Fig. 1

\section{FTIR Spectra}

To trace the structural changes of lignin during the ultrasound-assisted organic solvents and alkaline solutions extractions, FTIR spectra of three organosolv lignin preparations $\left(\mathrm{L}_{1}, \mathrm{~L}_{2}\right.$, and $\left.\mathrm{L}_{4}\right)$ and three alkaline lignin preparations $\left(\mathrm{L}_{5}, \mathrm{~L}_{6}\right.$, and $\left.\mathrm{L}_{7}\right)$ are shown (Fig. 2). It was clear to note that the spectra in Fig. 2 (a) and (b) were distinct in terms of the locations and intensities of the absorption bands. The bands at 1597, 1509, and $1420 \mathrm{~cm}^{-1}$, corresponding to aromatic skeletal vibrations and the $\mathrm{C}-\mathrm{H}$ deformation combined with aromatic ring vibration at $1462 \mathrm{~cm}^{-1}$, are present in Fig. 2 (b). In Fig. 2 (a), the three organosolv lignin preparations have rather similar FT-IR spectra, however, not typical of hardwood lignin. These obvious differences proved that the aromatic structure of the three organosolv lignin preparations had been degraded significantly when compared to the three alkaline lignin preparations. This was in accordance with the results obtained from GPC, which indicated molecular weights of 910 to $1030 \mathrm{~g} / \mathrm{mol}$ for the three organosolv lignin preparations in Fig. 2 (a), while 2000 to $2770 \mathrm{~g} / \mathrm{mol}$ for the three alkaline lignin preparations in Fig. 2 (b). Another reason might be the high content of carbohydrate in the three organosolv lignin preparations, ranging from $12.11 \%$ to $13.15 \%$, which could affect the absorption bands of lignin. In Fig. 2 (a), the absorptions at around $1726 \mathrm{~cm}^{-1}$ in all the three spectra are assigned to $\mathrm{C}=\mathrm{O}$ stretching of unconjugated ketone, carbonyl, and ester groups. The small band at $950 \mathrm{~cm}^{-1}$ in the spectra of $\mathrm{L}_{2}$ and $\mathrm{L}_{4}$ might arise from the absorption of xyloglucan (Kačuráková et al. 2000). This was in line with the results obtained by sugar analysis. A weak band at $1637 \mathrm{~cm}^{-1}$ in the spectrum of $\mathrm{L}_{1}$ is most likely derived from the ring-conjugated $\alpha, \beta$ unsaturated bond (Kihara et al. 2002). Other characteristic absorption peaks of lignin would be discussed in 
detail in Fig. 2 (b).

As shown in Fig. 2 (b), a wide absorption band at $3353 \mathrm{~cm}^{-1}$ originated from the $\mathrm{O}-\mathrm{H}$ stretching vibration in aromatic and aliphatic OH groups, while the bands at 2936 and $2849 \mathrm{~cm}^{-1}$ arise from the C-H asymmetric and symmetrical vibrations in methyl and methylene groups, respectively. A significant difference between the three alkaline lignin preparations is the strong absorption at $1709 \mathrm{~cm}^{-1}$ in the spectrum of $\mathrm{L}_{5}$, corresponding to non-conjugated carbonyl stretching, which disappears in $\mathrm{L}_{6}$ and $\mathrm{L}_{7}$. In the meantime, the intensity of the absorption at $1667 \mathrm{~cm}^{-1}$ increasing from $\mathrm{L}_{5}$ to $\mathrm{L}_{7}$, represents the carbonyl stretching in conjugated $p$-substituted aryl ketones. Syringyl and condensed guaiacyl absorptions are obviously seen at $1328 \mathrm{~cm}^{-1}$, and guaiacyl ring breathing with $\mathrm{C}=\mathrm{O}$ stretching appears at $1265 \mathrm{~cm}^{-1}$. The strong band at $1226 \mathrm{~cm}^{-1}$ is due to the $\mathrm{C}-\mathrm{C}, \mathrm{C}-\mathrm{O}$ and $\mathrm{C}=\mathrm{O}$ stretching. The maximum absorption band at $1124 \mathrm{~cm}^{-1}$ in Fig. 2 (b) indicated that all the three alkaline lignin preparations are GS lignins (Faix 1991). Besides, the band at $1032 \mathrm{~cm}^{-1}$ is indicative of the aromatic C-H in-plane deformation. According to the lignin classification system of Faix (1991), the intensity ratio of $1509 \mathrm{~cm}^{-1} / 1462 \mathrm{~cm}^{-1}$ increasing from $\mathrm{L}_{5}$ to $\mathrm{L}_{7}$ indicated that the content of $\mathrm{S}$ units in the three alkaline lignin preparations decreased from $\mathrm{L}_{5}$ to $\mathrm{L}_{7}$. Furthermore, the $\mathrm{A}_{1462} / \mathrm{A}_{1597}$ ratio in Fig. 2 (b) directly related to the amounts of methoxyl groups (Sarkanen et al. 1967), was smaller in $\mathrm{L}_{7}$ than in $\mathrm{L}_{5}$ and $\mathrm{L}_{6}$. This result also revealed that $\mathrm{L}_{7}$ contained fewer amounts of $\mathrm{S}$ units than $\mathrm{L}_{5}$ and $\mathrm{L}_{6}$.
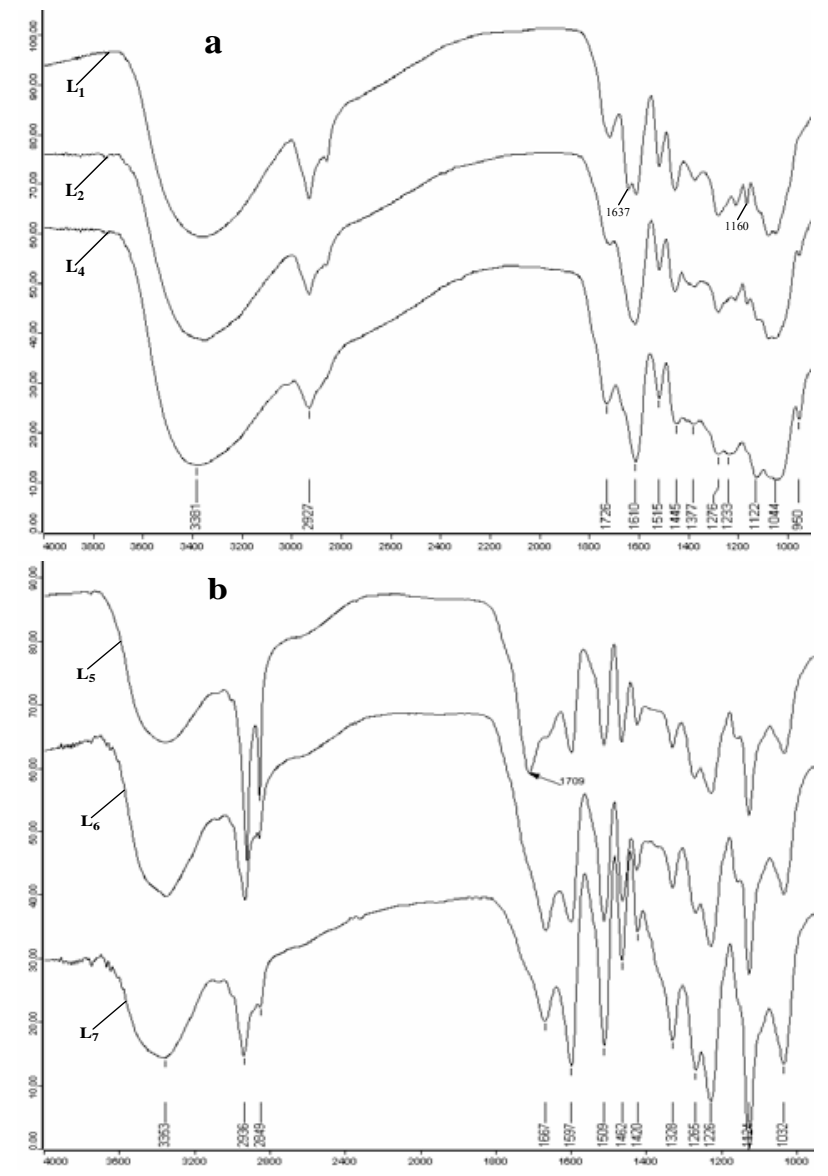

Fig. 2. FTIR spectra of three organosolv lignin preparations $\left(a, L_{1}, L_{2}\right.$, and $\left.L_{4}\right)$ and three alkaline lignin preparations $\left(b, L_{5}, L_{6}\right.$, and $\left.L_{7}\right)$ 


\section{Quantitative ${ }^{13} \mathrm{C}$ NMR Spectrum}

To further investigate the structural features of the lignin preparations, the highest yield lignin preparation $\mathrm{L}_{5}$, extracted from the ultrasonically pretreated material with $70 \%$ ethanol containing $1 \% \mathrm{NaOH}$ at $75{ }^{\circ} \mathrm{C}$ for $3 \mathrm{~h}$, was investigated with quantitative ${ }^{13} \mathrm{C}$ NMR spectrometry. The quantitative ${ }^{13} \mathrm{C}$ NMR spectrum of $\mathrm{L}_{5}$ is shown in Fig. 3. Most of the observed signals have been previously assigned in wood lignin spectra (Lapierre et al. 1982; Capanema et al. 2005). The integral at 160 to $102 \mathrm{ppm}$ was set as the reference, assuming that it includes six aromatic carbons. All structural moieties were expressed per one aromatic ring (Ar). The absence of signals between 90 and $102 \mathrm{ppm}$ indicates a low concentration of residual sugars in this lignin preparation. This was in line with the result obtained by sugar analysis, just $1.20 \%$ of associated hemicelluloses in $\mathrm{L}_{5}$. The strong peak at $174.4 \mathrm{ppm}$ and the weak peaks between 171 and $173 \mathrm{ppm}$ are attributed to carbon in carbonyl and carboxyl groups, which may originate from aliphatic carboxyl and aliphatic esters. In the aromatic region (153 to $103 \mathrm{ppm})$, the syringyl (S) units are detected by signals at 152.7 and $152.1 \mathrm{ppm}$ (C-3/C-5, etherified) and $147.5 \mathrm{ppm}$ (C-3/C-5, non-etherified), $138.1 \mathrm{ppm}$ (C-4, etherified), 134.8 and $134.3 \mathrm{ppm}$ (C-1, etherified), and $104.3 \mathrm{ppm}(\mathrm{C}-2 / \mathrm{C}-6)$. The guaiacyl $(\mathrm{G})$ units produce signals at $149.2 \mathrm{ppm}$ (C-3, etherified), $147.5 \mathrm{ppm}$ (C-4, etherified), $145.4 \mathrm{ppm}$ (C-4, non-etherified), 134.8 and 134.3 ppm (C-1, etherified), $115.2 \mathrm{ppm}$ (C-5), and $111.2 \mathrm{ppm}(\mathrm{C}-2)$. The $p$-hydroxyphenyl $(\mathrm{H})$ units appear as two signals at 128.0 and $129.2 \mathrm{ppm}(\mathrm{C}-2 / \mathrm{C}-6)$. The syringyl to guaiacyl ratio $(\mathrm{S} / \mathrm{G})$ was about $1.5: 1$, which was calculated on the basis of the number of carbons per aromatic ring in C-2/C-6 of syringyl unit and C-2 of guaiacyl unit (Capanema et al. 2005). Furthermore, the signals arising from the esterified $p$-hydroxybenzonic acid should be noted. This structural moiety is made evident by signals at $167.2 \mathrm{ppm}(\mathrm{C}=\mathrm{O})$, 161.8 ppm (C-4), 131.4 ppm (C-2/C-6), 121.3 ppm (C-1), and 114.9 ppm (data not shown, C-3/C-5). The sharp signals of this minor component suggested that they could be assigned to $p$-hydroxybenzoic units more mobile than the syringyl and guaiacyl ones constitutive of the lignin core (Lapierre et al. 1982). All these signals showed that this lignin preparation contained a certain amount of esterified $p$-hydroxybenzonic acids.

In the oxygenated and non-oxygenated inter-unit linkages region of lignin, the $\beta-O-4$ ' linkages were detected by signals at $86.0\left(\mathrm{C}_{\beta}\right.$ in $\mathrm{S} \beta-O-4$ ' erythro $), 85.1\left(\mathrm{C}_{\beta}\right.$ in $\mathrm{G}$ $\beta-O-4$ ' threo), $72.2\left(\mathrm{C}_{\alpha}\right.$ in $\beta-O-4$ ' $\mathrm{G}$ and $\mathrm{S}$ erythro), $71.4\left(\mathrm{C}_{\alpha}\right.$ in $\beta-O-4$ ' $\mathrm{G}$ and $\mathrm{S}$ threo $)$, 60.7 , and $59.6\left(\mathrm{C}_{\gamma}\right.$ in $\beta-O-4$ ' $\mathrm{G}$ and $\mathrm{S}$ threo and erythro) ppm. The strong signal at 55.9 ppm is attributed to the $-\mathrm{OCH}_{3}$ groups in $\mathrm{S}$ and $\mathrm{G}$ units. A small signal at $53.8 \mathrm{ppm}$ belongs to the $C_{\beta}$ in $\beta-\beta$ ' structure. According to Capanema et al. (2005) the integral at 54 to $53 \mathrm{ppm}$ could be used to estimate the amount of $\beta-\beta$ ' structure as ca. $0.06 / \mathrm{Ar}$. The cluster at 87.5 to $82.5 \mathrm{ppm}$ embodies moieties with the total amount of $\beta-O-4$ ', $\beta-\beta$ ', and $\beta-5$ structures. In the spectrum the signals of $\beta-5$ structure were found to be trace. So subtracting the amount of $\beta-\beta$ ' structure from the integral value of this region gives the total amount of $\beta-O-4$ ' as ca. $0.31 /$ Ar. Besides, the amount of $-\mathrm{OCH}_{3}$ was estimated from the integral at 57 to $54 \mathrm{ppm}$ as ca. 1.73/Ar. In addition, the signals between 13.9 and 33.7 ppm represent the $\gamma$-methyl, as well as the $\alpha$ - and $\beta$-methylene groups in $n$-propyl side chains of the lignin preparation. 


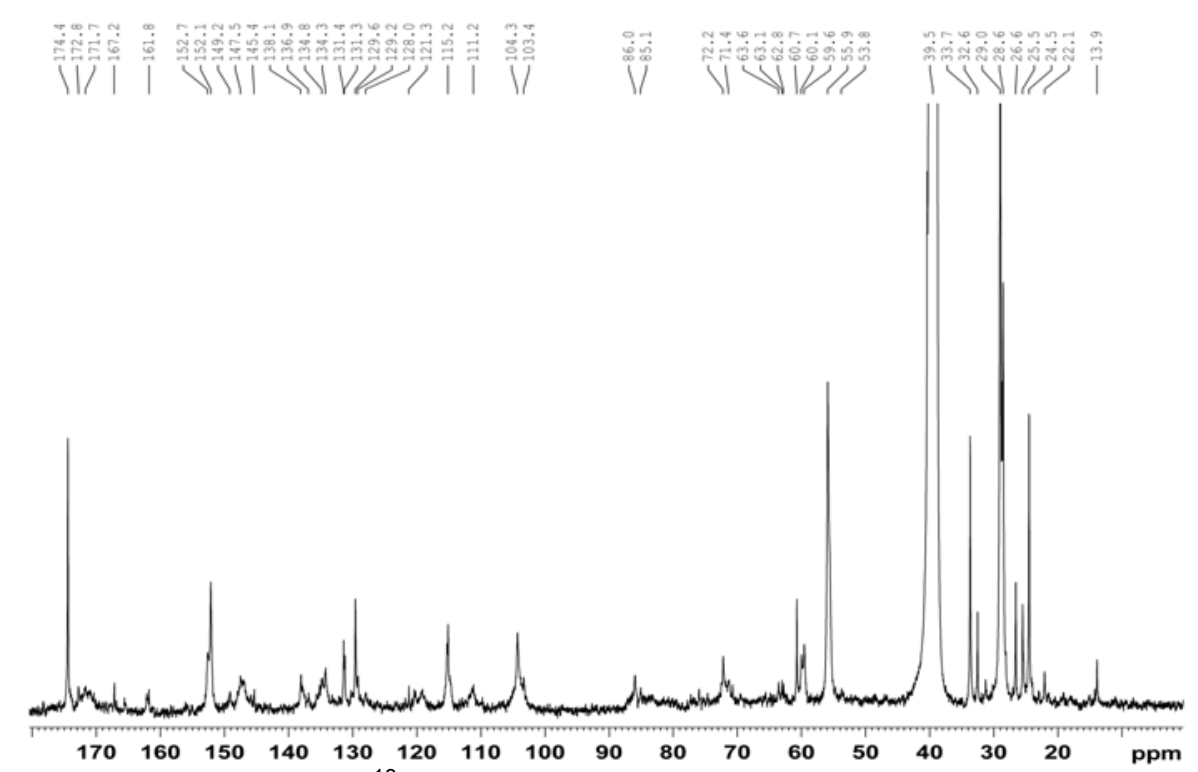

Fig. 3. Quantitative ${ }^{13} \mathrm{C}$ NMR spectrum of alkaline lignin preparation $L_{5}$

\section{D HSQC NMR Spectra}

For a more complete structural characterization of the lignin preparation, the highest yield alkaline lignin preparation $\mathrm{L}_{5}$ was subjected to $2 \mathrm{D}-\mathrm{NMR}$ analysis. Generally, most NMR studies of lignins were carried out in acetylated samples to increase their solubility. However, this prevented the detection of natural acetylation. In the present study, the HSQC NMR spectrum of $\mathrm{L}_{5}$ was acquired from underivatized sample. The HSQC NMR spectrum of $\mathrm{L}_{5}$ showed three regions corresponding to aliphatic, side chain, and aromatic ${ }^{13} \mathrm{C}-{ }^{1} \mathrm{H}$ correlations. The aliphatic (nonoxygenated) region showed signals with no structural information and therefore is not discussed in detail. The side-chain $\left(\delta_{\mathrm{C}} / \delta_{\mathrm{H}} 50-95 / 2.5-6.0\right)$ and the aromatic $\left(\delta_{\mathrm{C}} / \delta_{\mathrm{H}} 95-145 / 5.5-8.5\right)$ regions of the HSQC spectrum of $\mathrm{L}_{5}$ are shown in Fig. 4. The main lignin cross-signals assigned in the HSQC spectra are listed in Table 5, and the main substructures are depicted in Fig. 5.

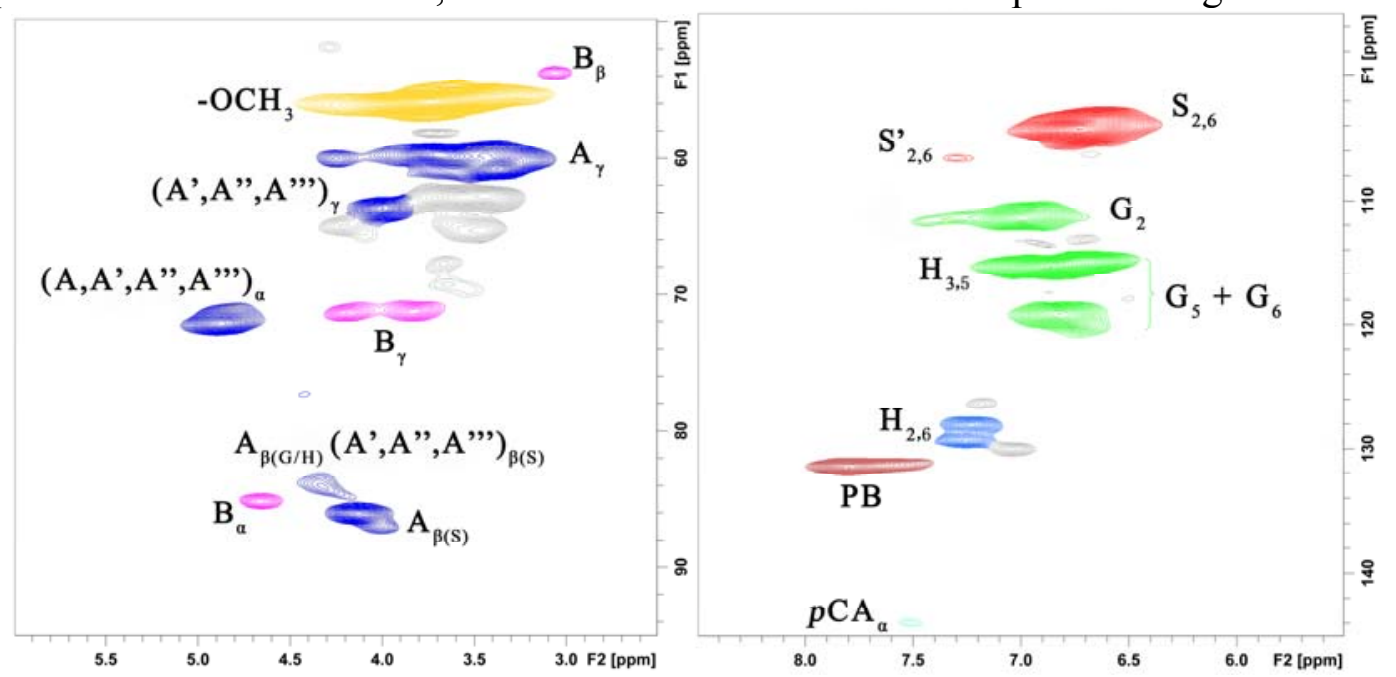

Fig. 4. Side-chain (left column) and aromatic regions (right column) in the $2 \mathrm{D}$ HSQC NMR spectrum: $\delta_{\mathrm{C}} / \delta_{\mathrm{H}} 50-95 / 2.5-6.0 \mathrm{ppm}$ and $\delta_{\mathrm{C}} / \delta_{\mathrm{H}} 95-145 / 5.5-8.5 \mathrm{ppm}$, respectively. Symbols are taken from Fig. 5. See Table 5 for signal assignment. 
Table 5. Assignment of Main Lignin ${ }^{13} \mathrm{C}-{ }^{1} \mathrm{H}$ Cross-Signals in the HSQC Spectrum of the Alkaline Lignin Preparation $\mathrm{L}_{5}$

\begin{tabular}{|c|c|c|}
\hline Labels & $\delta_{\mathrm{C}} / \delta_{\mathrm{H}}(\mathrm{ppm})$ & Assignment \\
\hline $\mathrm{B}_{\beta}$ & $53.7 / 3.05$ & $\mathrm{C}_{\beta}-\mathrm{H}_{\beta}$ in resinol substructures (B) \\
\hline$-\mathrm{OCH}_{3}$ & $55.9 / 3.73$ & $\mathrm{C}-\mathrm{H}$ in methoxyls \\
\hline $\mathrm{A}_{\gamma}$ & $\begin{array}{l}59.6-60.8 / \\
3.37-3.71\end{array}$ & $\mathrm{C}_{\gamma}-\mathrm{H}_{\gamma}$ in $\beta-O-4$ ' substructures $(A)$ \\
\hline$\left(\mathrm{A}^{\prime}, \mathrm{A}^{\prime \prime}, \mathrm{A}^{\prime \prime \prime}\right)_{\gamma}$ & $63.6 / 3.98$ & $\mathrm{C}_{\gamma}-\mathrm{H}_{\gamma}$ in $\gamma$-acylated $\beta$-O-4' substructures (A',A',,A'”) \\
\hline $\mathrm{B}_{\gamma}$ & $\begin{array}{l}71.3 / 4.18 \\
71.3 / 3.82\end{array}$ & $\mathrm{C}_{V}-\mathrm{H}_{V}$ in resinol substructures $(\mathrm{B})$ \\
\hline $\mathrm{A}_{\alpha}$ & $72.2 / 4.86$ & $\mathrm{C}_{\alpha}-\mathrm{H}_{\alpha}$ in $\beta-O-4$ ' substructures $(\mathbf{A})$ \\
\hline$\left(\mathrm{A}^{\prime}, \mathrm{A}^{\prime \prime}, \mathrm{A}^{\prime \prime \prime}\right)_{\alpha}$ & $72.2 / 4.86$ & $\mathrm{C}_{\alpha}-\mathrm{H}_{\alpha}$ in $\mathrm{\gamma}$-acetylated $\beta$-O-4' substructures (A',A",,A'”) \\
\hline$A_{\beta(G / H)}$ & $83.9 / 4.30$ & $\mathrm{C}_{\beta}-\mathrm{H}_{\beta}$ in $\beta-O-4$ ' substructures linked to a $\mathrm{G}$ unit $(\mathbf{A})$ \\
\hline$\left(\mathrm{A}^{\prime}, \mathrm{A}^{\prime \prime}, \mathrm{A}^{\prime \prime \prime}\right)_{\beta(\mathrm{S})}$ & $83.9 / 4.30$ & $\begin{array}{l}\mathrm{C}_{\beta}-\mathrm{H}_{\beta} \text { in } \gamma \text {-acylated } \beta-O-4 \text { ' substructures linked to a } \mathrm{S} \text { unit } \\
\left(\mathbf{A}^{\prime}, \mathbf{A}^{\prime \prime}, \mathbf{A}^{\prime \prime \prime}\right)\end{array}$ \\
\hline$A_{\beta(S)}$ & $86.0 / 4.11$ & $\mathrm{C}_{\beta}-\mathrm{H}_{\beta}$ in $\beta-O-4$ ' substructures linked to a $\mathrm{S}$ unit $(\mathrm{A})$ \\
\hline $\mathrm{B}_{\alpha}$ & $85.1 / 4.66$ & $\mathrm{C}_{\alpha}-\mathrm{H}_{\alpha}$ in resinol substructures $(\mathrm{B})$ \\
\hline $\mathrm{C}_{\alpha}$ & $87.1 / 5.51$ & $\mathrm{C}_{\alpha}-\mathrm{H}_{\alpha}$ in phenylcoumaran substructures (C) \\
\hline $\mathrm{S}_{2,6}$ & $104.3 / 6.71$ & $\mathrm{C}_{2,6}-\mathrm{H}_{2,6}$ in etherified syringyl units (S) \\
\hline $\mathrm{S}_{2,6}^{\prime}$ & $106.6 / 7.32$ & $\mathrm{C}_{2,6}-\mathrm{H}_{2,6}$ in oxidized $\left(\mathrm{C}_{\alpha}=\mathrm{O}\right)$ phenolic syringyl units ( $\left.\mathbf{S}^{\prime}\right)$ \\
\hline $\mathrm{G}_{2}$ & $111.3 / 6.99$ & $\mathrm{C}_{2}-\mathrm{H}_{2}$ in guaiacyl units $(\mathbf{G})$ \\
\hline $\mathrm{G}_{5}$ & $\begin{array}{l}114.9-115.2 / \\
6.80-6.86\end{array}$ & $\mathrm{C}_{2}-\mathrm{H}_{2}$ in guaiacyl units $(\mathbf{G})$ \\
\hline $\mathrm{G}_{6}$ & $119.1 / 6.80$ & $\mathrm{C}_{6}-\mathrm{H}_{6}$ in guaiacyl units $(\mathbf{G})$ \\
\hline $\mathrm{H}_{2,6}$ & $\begin{array}{l}128.0-129.2 / \\
7.23-7.24\end{array}$ & $\mathrm{C}_{2,6}-\mathrm{H}_{2,6}$ in $p$-hydroxyphenyl units $(\mathbf{H})$ \\
\hline $\mathrm{PB}_{2,6}$ & $131.4 / 7.78$ & $\mathrm{C}_{2,6}-\mathrm{H}_{2,6}$ in sinapyl $p$-hydroxybenzoate substructures (PB) \\
\hline$p C A_{\alpha}$ & $143.9 / 7.50$ & $\mathrm{C}_{\alpha}-\mathrm{H}_{\alpha}$ in $p$-coumarate substructures $(\boldsymbol{p C A})$ \\
\hline
\end{tabular}

In the side-chain region of the HSQC spectrum, cross-signals of methoxyls $\left(\delta_{\mathrm{C}} / \delta_{\mathrm{H}}\right.$ $55.9 / 3.73$ ) and side-chains in $\beta-O-4$ ' aryl ether linkages were the most prominent in $\mathrm{L}_{5}$. The $\mathrm{C}_{\alpha}-\mathrm{H}_{\alpha}$ correlations in $\beta-O-4$ ' substructures were observed at $\delta_{\mathrm{C}} / \delta_{\mathrm{H}} 72.2 / 4.86$ (structures A, A', A', and A'”'). Likewise, $\mathrm{C}_{\beta}-\mathrm{H}_{\beta}$ correlations were observed at $\delta_{\mathrm{C}} / \delta_{\mathrm{H}}$ 86.0/4.11 for structure A linked to $\mathbf{S}$ lignin unit. These correlations shifted to $\delta_{\mathrm{C}} / \delta_{\mathrm{H}}$ 83.9/4.30 in structure $\mathbf{A}$ linked to $\mathbf{G} / \mathbf{H}$ lignin units and $\gamma$-acylated $\beta-O-4$ ' aryl ether substructures (A', A', and A'"') linked to $\mathbf{S}$ lignin unit. The $\mathrm{C}_{\gamma}-\mathrm{H}_{\gamma}$ correlations in $\beta-O-4$ ' substructures were observed at $\delta_{\mathrm{C}} / \delta_{\mathrm{H}}$ 59.6-60.8/3.37-3.71 (structures A). Moreover, a weak signal was observed at $\delta_{\mathrm{C}} / \delta_{\mathrm{H}} 63.6 / 3.98$, which should be attributed to $\mathrm{C}_{\gamma}-\mathrm{H}_{\gamma}$ correlations in $\gamma$-acylated lignin units (A', A', and A'”). These signals indicate that the lignin from fast-growing poplar wood is partially acylated at the $\gamma$-carbon in $\beta-O-4$ ' aryl ether linkages of the side chains. However, some natural esterified groups present on lignin might have been hydrolyzed and removed when using the present isolation method. Therefore, further studies of milled wood lignin from the fast-growing poplar wood will be needed. It should be mentioned that $\gamma$-acylated $\mathbf{G}$ and $\mathbf{S}$ units have been detected in the lignins of many species. For instance, sinapyl acetate is implicated similarly as a monomer in lignification in kenaf bast fibers (Lu and Ralph 2002). The lignin of grasses is adorned with $\gamma$ - $p$-coumarate substituents on a variety of lignin units. 
In addition to $\beta-O-4$ ' substructures, other linkages were also observed. Strong signals for resinol $\left(\beta-\beta^{\prime} / \alpha-O-\gamma^{\prime} / \gamma-O-\alpha^{\prime}\right)$ substructures $(\mathbf{B})$ were observed in the spectrum, with their $\mathrm{C}_{\alpha}-\mathrm{H}_{\alpha}$ and $\mathrm{C}_{\beta}-\mathrm{H}_{\beta}$ correlations at $\delta_{\mathrm{C}} / \delta_{\mathrm{H}} 85.1 / 4.66$ and 53.7/3.05, respectively. However, the $\mathrm{C}_{\gamma}-\mathrm{H}_{\gamma}$ correlations in these two substructures were disparate. The $\mathrm{C}_{\gamma}-\mathrm{H}_{\gamma}$ correlations in substructures $\mathbf{B}$ were observed at $\delta_{\mathrm{C}} / \delta_{\mathrm{H}} 71.3 / 4.18$ and 71.3/3.82. Furthermore, a small signal of phenylcoumaran ( $\beta-5$, linkages) may only be seen at lower contour levels (not shown). Its $\mathrm{C}_{\alpha}-\mathrm{H}_{\alpha}$ correlation could be observed at $\delta_{\mathrm{C}} / \delta_{\mathrm{H}} 87.1 / 5.51$. It should be noted that this signal is too weak and could not be detected in the quantitative ${ }^{13} \mathrm{C}$ NMR spectrum.

In the aromatic region of the HSQC spectrum, cross-signals from syringyl (S) and guaiacyl (G) lignin units could be observed. The S-lignin units showed a prominent signal for the $\mathrm{C}_{2,6}-\mathrm{H}_{2,6}$ correlation at $\delta_{\mathrm{C}} / \delta_{\mathrm{H}} 104.3 / 6.71$, while the $\mathbf{G}$ units showed different correlations for $\mathrm{C}_{2}-\mathrm{H}_{2}, \mathrm{C}_{5}-\mathrm{H}_{5}$, and $\mathrm{C}_{6}-\mathrm{H}_{6}$ at $\delta_{\mathrm{C}} / \delta_{\mathrm{H}} 111.3 / 6.99,114.9 / 6.74-115.2 / 6.86$, and 119.1/6.80, respectively. The double $\mathrm{C}_{5}-\mathrm{H}_{5}$ signal revealed some heterogeneity among the $\mathbf{G}$ units especially affecting the $\mathrm{C}_{5}-\mathrm{H}_{5}$ correlation, probably because it is due to different substituents at $\mathrm{C}_{4}$ (e.g. phenolic or etherified in different substructures). Signals corresponding to $\mathrm{C}_{2,6}-\mathrm{H}_{2,6}$ correlations in $\mathrm{C}_{\alpha}$-oxidized $\mathrm{S}$ units (S') $\left(\delta_{\mathrm{C}} / \delta_{\mathrm{H}} 106.6 / 7.32\right)$ were present in the HSQC spectrum of $\mathrm{L}_{5}$. These signals have also been found in the HSQC spectra of other lignin samples, such as the MWL from eucalypt wood and some nonwoody plants (del Río et al. 2008; Martínez et al. 2008; Rencoret et al. 2009).

Other significant signals in the aromatic region of the HSQC spectrum are assigned to $p$-hydroxyphenyl units $(\mathbf{H})$ and sinapyl $p$-hydroxybenzoate substructures (PB). The $\mathrm{C}_{2,6}-\mathrm{H}_{2,6}$ aromatic correlations from $p$-hydroxyphenyl (H) units were clearly observed at 128.0-129.2/7.23-7.24 ppm, but the $\mathrm{C}_{3,5}-\mathrm{H}_{3,5}$ position correlations were overlapped with those from guaiacyl 5-positions. A strong signal for the $\mathrm{C}_{2,6}-\mathrm{H}_{2,6}$ correlations of sinapyl $p$-hydroxybenzoate substructures (PB) were also observed at $\delta_{\mathrm{C}} / \delta_{\mathrm{H}}$ 131.4/7.78. This result was in line with the lignin structural analyses of poplar, aspen, willow, and palm, which have shown that $\gamma$ - $p$-hydroxybenzoate esters are present (Smith 1955; Landucci et al. 1992; Sun et al. 1999; Meyermans et al. 2000; Morreel et al. 2004). Most importantly, Morreel et al. (2004) had found that only $S$ units are $\gamma$ - $p$-hydroxybenzoylated in poplar lignin and the sinapyl $p$-hydroxybenzoate is produced enzymatically and used as an authentic monomer for lignification in poplar. Furthermore, a weak signal for the $\mathrm{C}_{\alpha}-\mathrm{H}_{\alpha}$ correlation of $p$-coumarate substructures (pCA) was found at $\delta_{\mathrm{C}} / \delta_{\mathrm{H}} 143.9 / 7.50$.

The major lignin structural features were investigated for $\mathrm{L}_{5}$, such as the percentage of the main inter-unit linkages (referred to as the total side-chains) and $\mathrm{S} / \mathrm{G}$ ratio. As expected, the main substructures present in $\mathrm{L}_{5}$ were the $\beta-O-4$ ' linked ones (A, A', A', and A','), which accounted for $83 \%$ of all side-chains, followed by the $\beta-\beta$ ' resinol substructures $(\mathbf{B})$ that involved $16 \%$ of all side-chains. Besides, a trace amount of $\beta-5$ ' phenylcoumaran-type (1\%) linkages was also detected in $\mathrm{L}_{5}$. Moreover, the ratio of $\mathrm{S} / \mathrm{G}$ was calculated to be 2.0 . 
<smiles>COc1cc([C@H](O)[C@@H](CO)Oc2c(OC)cc(C(=O)O)cc2OC)cc(OC)c1OC</smiles>

$\mathbf{A}$<smiles>CCOc1c(OC)cc([C@H](O)[C@@H](COC(C)=O)Oc2c(OC)cc(C(=O)OC)cc2OC)cc1OC</smiles>

$\mathbf{A}^{\prime}$

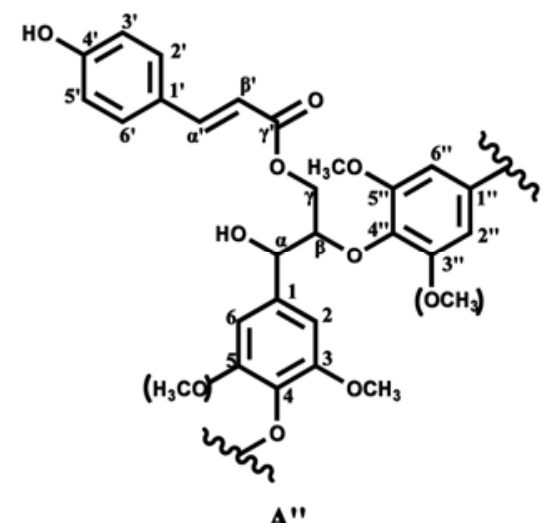<smiles>COCCOc1c(OC)cc([C@@H](O)[C@@H](COC(=O)c2ccc(O)cc2)Oc2c(OC)cc(OC)cc2OC)cc1OC</smiles><smiles>CCOc1c(OC)cc(C2OC[C@H]3C(c4cc(OC)c(OC(C)(C)C)c(OC)c4)OC[C@@H]23)cc1OC</smiles>

B

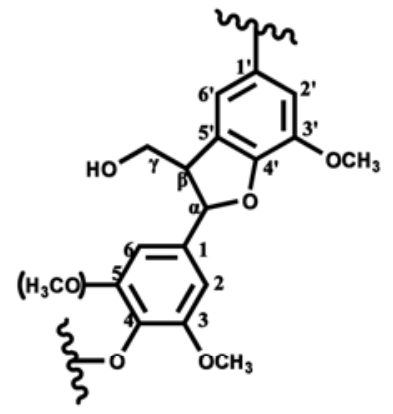

C<smiles>CCOc1ccc(C(C)C)cc1</smiles>

H<smiles>COC(=O)C(C)(C)COc1cc(C(C)C)ccc1OC</smiles>

G<smiles>CCCC(O)c1cc(OC)c(OCC)c(OC)c1</smiles>

$\mathbf{S}$<smiles>CCCC(=O)c1cc(OC)c(O)c(OC)c1</smiles>

$\mathbf{S}^{\prime}$<smiles>COC(=O)/C=C/c1ccc(O)cc1</smiles>

pCA<smiles>COC(=O)c1ccc(O)cc1</smiles>

PB

Fig. 5. Main classical and acetylated substructures, involving different side-chain linkages, and aromatic units identified by 2D NMR of alkaline lignin preparation L5: (A) $\beta$-O-4' aryl ether linkages with a free $-\mathrm{OH}$ at the $\gamma$-carbon; $\left(\mathbf{A}^{\prime}\right) \beta-\mathrm{O}-4^{\prime}$ aryl ether linkages with acetylated $-\mathrm{OH}$ at $\gamma$-carbon; (A") $\beta$-O-4' aryl ether linkages with $p$-coumaroylated -OH at $\gamma$-carbon; ( $\left.\mathbf{A}^{\prime \prime \prime}\right) \beta$-O-4' aryl ether linkages with $p$-hydroxybenzoated $-\mathrm{OH}$ at $\gamma$-carbon; (B) resinol substructures formed by $\beta-\beta$, $\alpha-O-\gamma^{\prime}$, and $\gamma-O-\alpha^{\prime}$ linkages; (C) phenylcoumarane substructures formed by $\beta-5$ ' and $\alpha-O-4$ ' linkages; (H) p-hydroxyphenyl unit; (G) guaiacyl unit; (S) syringyl unit; (S') oxidized syringyl units with a $\mathrm{C}_{\alpha}$ ketone; ( $\left.\boldsymbol{p C A}\right) p$-coumarate; (PB) $p$-hydroxybenzoate substructures.

\section{Thermal stability}

Lignins are utilized in a wide variety of applications, some of which involve brief exposure to moderately high temperatures, and in such applications the thermal stability is an issue (Domínguez et al. 2008). In the present study the thermal degradation of organosolv lignin preparation $\mathrm{L}_{4}$ and alkaline lignin preparation $\mathrm{L}_{5}$ have been 
comparatively investigated using the techniques of thermogravimetric analysis (TGA) between room temperature and $600{ }^{\circ} \mathrm{C}$. The thermogravimetric analysis (TGA) and 1 st derivative thermogravimetric (DTG) curves are illustrated in Fig. 6. As shown in Fig. 6, the thermal degradation of both lignin preparations proceeded over a wide temperature range $\left(100\right.$ to $\left.600{ }^{\circ} \mathrm{C}\right)$. At $10 \%$ and $50 \%$ weight loss, the decomposition temperatures were determined to be $191{ }^{\circ} \mathrm{C}$ and $440{ }^{\circ} \mathrm{C}$ for $\mathrm{L}_{4}$ and $265{ }^{\circ} \mathrm{C}$ and $520{ }^{\circ} \mathrm{C}$ for $\mathrm{L}_{5}$, respectively. Furthermore, the DTG curves present the weight loss rates, while the DTG $_{\max }$ represents the maximum degradation rate, which can be used for the comparison of the thermal stability between the samples (Nadji et al. 2009). The $\mathrm{DTG}_{\max }$ values were found to be $213{ }^{\circ} \mathrm{C}$ for $\mathrm{L}_{4}$ and $281{ }^{\circ} \mathrm{C}$ and $516{ }^{\circ} \mathrm{C}$ for $\mathrm{L}_{5}$. The differences in the inherent structures and chemical nature of the two lignin preparations possibly account for the different behaviors observed. The results from GPC indicated that the molecular-average weight of $\mathrm{L}_{5}(2000 \mathrm{~g} / \mathrm{mol})$ was higher than that of $\mathrm{L}_{4}(1030 \mathrm{~g} / \mathrm{mol})$. The thermal stability of the lignin preparations were found to increase with increasing molecular weight.

Recently, Yang et al. (2006) studied the pyrolysis behaviors of mixtures of hemicelluloses and lignin. They found that the temperature of $\mathrm{DTG}_{\max }$ decreased with the increase in hemicelluloses content. In the present study, sugar analysis revealed that $\mathrm{L}_{4}$ was much higher in hemicelluloses content than $\mathrm{L}_{5}, 12.1 \%$ for $\mathrm{L}_{4}$ and just $1.2 \%$ for $\mathrm{L}_{5}$. Furthermore, a previous study (Jakab et al. 1997) has shown that the ether bonds between syringyl units are easier to split than those between guaiacyl units. The results from alkaline nitrobenzene oxidation revealed that the mole ratios of $\mathrm{S} / \mathrm{G}$ for $\mathrm{L}_{4}$ and $\mathrm{L}_{5}$ were 1.2:1 and $0.3: 1$, respectively. In other words, $\mathrm{L}_{4}$ contained more non-condensed syringyl units than $\mathrm{L}_{5}$. All these comparative analysis indicated that the alkaline lignin preparation $\mathrm{L}_{5}$ had a higher thermal stability than the organosolv lignin preparation $\mathrm{L}_{4}$ in the present experiment.

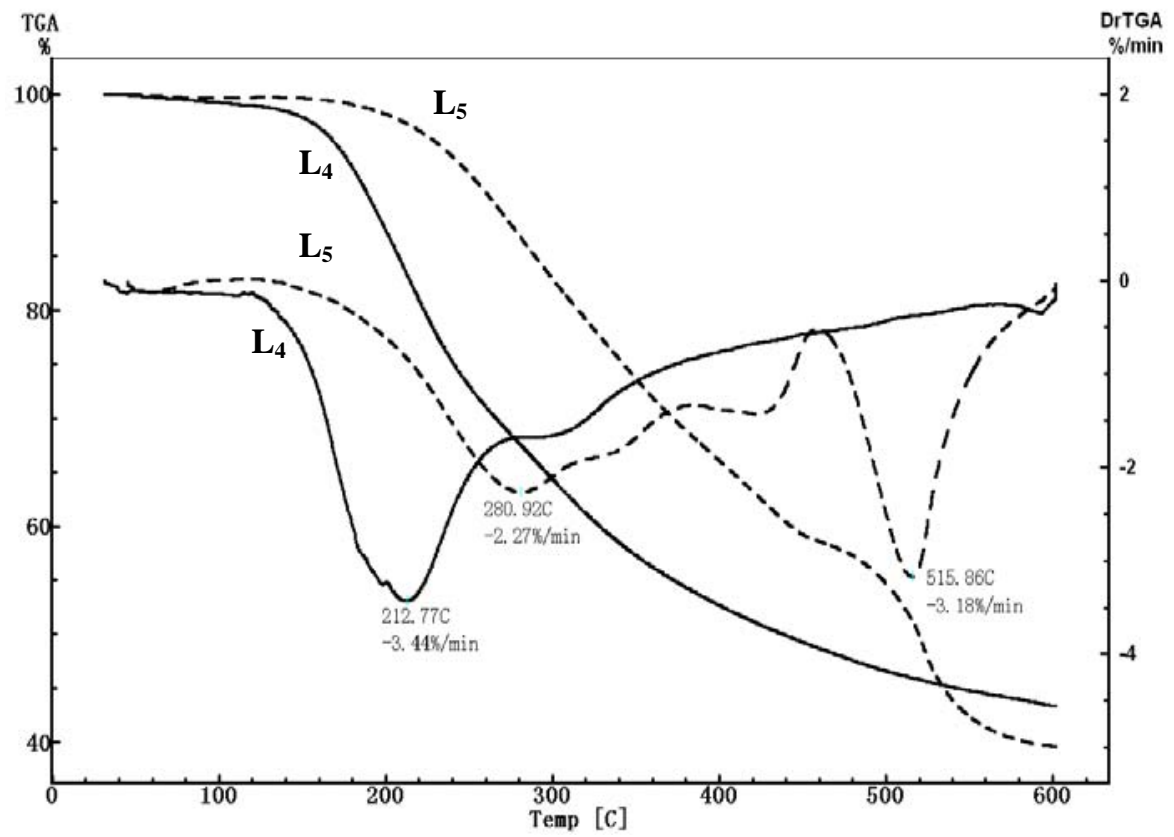

Fig. 6. TGA/DTG curves of organosolv lignin preparation $L_{4}$ and alkaline lignin preparation $L_{5}$ 


\section{CONCLUSIONS}

In the present study, it could be concluded that treatments with the combination of ultrasonically assisted organic solvents and alkaline solutions were an effective approach to remove lignin from the fast-growing poplar wood. Over $90 \%$ of the original lignin could be successively extracted from the ultrasound-pretreated material with a relatively low $\mathrm{NaOH}$ concentration. The yield, composition, physicochemical and thermal properties, and structural features of the obtained organosolv and alkaline lignin preparations were comparatively studied. Much significant structural information of the highest lignin-content preparation was obtained from quantitative ${ }^{13} \mathrm{C}$ and $2 \mathrm{D}$ HSQC NMR spectra. It was also found that the differences in the inherent structures and chemical nature of the lignin preparations play an important role in their thermal stability. In summary, we believe that the knowledge of the method to remove lignin from the cell wall and structural features of the lignin polymer of the fast-growing poplar wood will help to maximize the exploitation of this interesting wood for ethanol and paper production as well as the utilization of lignin for novel materials and chemicals.

\section{ACKNOWLEDGEMENTS}

The authors are grateful for the financial support of this research from the Fundamental Research Funds for the Central Universities (BLYJ200905), and partial support from Major State Basic Research Projects of China (973-2010CB732204), National Science Foundation of China (30930073/31070526), China Ministry of Education (111), and State Forestry Administration (200804015/2010-4-16).

\section{REFERENCES CITED}

Balan, V., Sousa, L. da C., Chundawat, S. P. S., Marshall, D., Sharma, L. N., Chambliss, C. K., and Dale, B. E. (2009). "Enzymatic digestibility and pretreatment degradation products of AFEX-treated hardwoods (Populus nigra)," Biotechnol. Prog. 25(2), 365-375.

Ballesteros, M., Oliva, J. M., Negro, M. J., Manzanares, P., and Ballesteros, I. (2004). "Ethanol from lignocellulosic materials by a simultaneous saccharification and fermentation process (SFS) with Kluyveromyces marxianus CECT 10875," Process Biochem. 39(12), 1843-1848.

Bose, S. K., Francis, R. C., Govender, M., Bush, T., and Spark, A. (2009). "Lignin content versus syringyl to guaiacyl ratio amongst poplars," Bioresour. Technol. 100(4), 1628-1633.

Capanema, E. A., Balakshin, M. Y., and Kadla, J. F. (2005). "Quantitative characterization of a hardwood milled wood lignin by nuclear magnetic resonance spectroscopy," J. Agric. Food Chem. 53(25), 9639-9649.

Davison, B. H., Drescher, S. R., Tuskan, G. A., Davis, M. F., and Nghiem, N. P. (2006). "Variation of S/G ratio and lignin content in a Populus family influences the release of xylose by dilute acid hydrolysis," Appl. Biochem. Biotechnol. 129-132, 427-435. 
del Río, J. C., Rencoret, J., Marques, G., Gutiérrez, A., Ibarra, D., Santos, J. I., Jiménez-Barbero, J., Zhang, L. M., and Martínez, Á. T. (2008). 'Highly acylated (acetylated and/or $p$-coumaroylated) native lignins from diverse herbaceous plants," $J$. Agric. Food Chem. 56(20), 9525-9534.

del Río, J. C., Rencoret, J., Marques, G., Li, J. B., Gellerstedt, G., Jiménez-Barbero, J., Martínez, Á. T., and Gutiérrez, A. (2009). "Structural Characterization of the Lignin from Jute (Corchorus capsularis) Fibers," J. Agric. Food Chem. 57(21), 10271-10281.

Domínguez, J. C., Oliet, M., Alonso, M. V., Gilarranz, M. A., and Rodríguez, F. (2008). "Thermal stability and pyrolysis kinetics of organosolv lignins obtained from Eucalyptus globules," Ind. Crops Prod. 27(2), 150-156.

Ebringerová, A., and Hromádková, Z. (2002). "Effect of ultrasound on the extractibility of corn bran hemicelluloses," Ultrason. Sonochem. 9(4), 225-229.

EI'Piner, I. E. (1964). Ultrasound: Physical, Chemical and Biological Effects, Consultants Bureau, New York.

Faix, O. (1991). "Classification of lignins from different botanical origins by FT-IR spectroscopy," Holzforschung 45(Suppl.), 21-27.

Fu, C. L., Tian, H. J., Li, Q. H., Cai, T. Y., and Du, W. J. (2006). "Ultrasound-assisted extraction of xyloglucan from apple pomace," Ultrason. Sonochem. 13(6), 511-516.

Govender, M., Bush, T., Spark, A., Bose, S. K., and Francis, R. C. (2009). "An accurate and non-labor intensive method for the determination of syringyl to guaiacyl ratio in lignin," Bioresour. Technol. 100(23), 5834-5839.

Higuchi, T. (1997). Biochemistry and Molecular Biology of Wood, Springer-Verlag, London.

Himmel, M. E., Ding, S. Y., Johnson, D. K., Andey, W. S., Nimlos, M. R., Brady, J. W., and Foust T. D. (2007). "Biomass recalcitrance: Engineering plants and enzymes for biofuels production,” Science 315(5813), 804-807.

Hromádková, Z., Ebringerová, A., and Valachovič, P. (1999). "Comparison of classical and ultrasound-assisted extraction of polysaccharides from Salvia officinalis L.," Ultrason. Sonochem. 5(4), 163-168.

Hromádková, Z., Ebringerová, A., and Valachovič, P. (2002). "Ultrasound-assisted extraction of water-soluble polysaccharides from the roots of valerian (Valeriana officinalis L.)," Ultrason. Sonochem. 9(1), 37-44.

Hromádková, Z., and Ebringerová, A. (2003). "Ultrasonic extraction of plant materials-investigation of hemicellulose release from buckwheat hulls," Ultrason. Sonochem. 10(3), 127-133.

http://wwwold.sdpc.gov.cn/1/1200402251.htm, last accessed March 30, 2010.

Jakab, E., Faix, O., and Till, F. (1997). "Thermal decomposition of milled wood lignins studied by thermogravimetry/mass spectrometry," J. Anal. Appl. Pyrol. 40-41, 171-186.

Kačuráková, M., Capek, P., Sasinková, V., Wellner, N., and Ebringerová, A. (2000). "FT-IR study of plant cell wall model compounds: Pectic polysaccharides and hemicelluloses," Carbohydr. Polym. 43(2), 195-203.

Kihara, M., Takayama, M., Wariishi, H., and Tanaka, H. (2002). "Determination of the carbonyl groups in native lignin utilizing Fourier transform Raman spectroscopy," Spectrochim. Acta A. 58(10), 2213-2221. 
Kleinert, M., and Barth, T. (2008). "Towards a lignincellulosic biorefinery: Direct one-step conversion of lignin to hydrogen-enriched biofuel," Energ. Fuel. 22(2), 1371-1379.

Kunkes, E. L., Simonetti, D. A., West, R. M., Serrano-Ruiz, J. C., Gärtner, C. A., and Dumesic, J. A. (2008). "Catalytic conversion of biomass to monofunctional hydrocarbons and targeted liquid-fuel classes," Science 322(5900), 417-421.

Landucci, L. L., Deka, G. C., and Roy, D. N. A. (1992). " ${ }^{13}$ C NMR study of milled wood lignins from hybrid Salix clones," Holzforschung 46(6), 505-511.

Lapierre, C., Lallemand, J. Y., and Monties, B. (1982). "Evidence of poplar lignin heterogeneity by combination of ${ }^{13} \mathrm{C}$ and ${ }^{1} \mathrm{H}$ NMR spectroscopy," Holzforschung 36(6), 275-282.

Li, X., Weng, J. K., and Chapple, C., (2008). "Improvement of biomass through lignin modification," Plant J. 54(4), 569-581.

Lu, F. C., and Ralph, J. (2002). "Preliminary evidence for sinapyl acetate as a lignin monomer in kenaf," Chem. Commun. 1, 90-91.

Lu, F. C., and Ralph, J. (2003). "Non-degradative dissolution and acetylation of ball-milled plant cell walls: high-resolution solution-state NMR," Plant J. 35, 535-544.

Lu, F. C., Ralph, J., Morreel, K., Messens, E., and Boerjan, W. (2004). "Preparation and relevance of a cross-coupling product between sinapyl alcohol and sinapyl p-hydroxybenzoate," Org. Biomol. Chem. 2, 2888-2890.

Martínez, Á. T., Rencoret, J., Marques, G., Gutiérrez, A., Ibarra, D., Jiménez-Barbero, J., and del Río, J. C. (2008). "Monolignil acylation and lignin structure in some nonwoody plants: A 2D NMR study," Phytochemistry 69(16), 2831-2843.

Meyermans, H., Morreel, K., Lapierre, C., Pollet, B., De Bruyn, A., Busson, R., Herdewijn, P., Devreese, B., Van Beeumen, J., Marita, J. M., Ralph, J., Chen, C., Burggraeve, B., Van Montagu, M., Messens, E., and Boerjan, W. (2000).

"Modification in lignin and accumulation of phenolic glucosides in poplar xylem upon downregulation of caffeoyl-coenzyme A O-methyltransferase, an enzyme involved in lignin biosynthesis," J. Biol. Chem. 275(47), 36899-36909.

Morreel, K., Ralph, J., Kim, H., Lu, F. C., Goeminne, G., Ralph, S., Messens, E., and Boerjan, W. (2004). "Profiling of oligolignols reveals monolignol coupling conditions in lignifying poplar xylem," Plant physiol. 136(3), 3537-3549.

Nadji, H., Diouf, P. N., Bedard, Y., Riedl, B., and Stevanovic, T. (2009). "Comparative study of lignins isolated from Alfa grass (Stipa tenacissima L.)," Bioresour. Technol. 100(14), 3585-3592.

Ragauskas, A. J., Williams, C. K., Davison, B. H., Britovsek, G., Cairney, J., Eckert, C. A., Frederick, W. J., Hallett, Jr., J. P., Leak, D. J., Liotta, C. L., Mielenz, J. R., Murphy, R., Templer, R., and Tschaplinski, T. (2006). "The path forward for biofuels and biomaterials," Science 311(5760), 484-489.

Ralph, J. (2007). "Perturbing lignification," in: The Compromised Wood Workshop, Entwistle, K., Harris, P. J., and Walker, J. (eds.), University of Canterbury, Christchurch, NZ.

Rencoret, J., Marques, G., Gutiérrez, A., Nieto, L., Jiménez-Barbero, J., Martínez, Á. T., and del Río, J. C. (2009). "Isolation and structural characterization of the milled-wood lignin from Paulownia fortunei wood," Ind. Crops Prod. 30(1), 
137-143.

Rodrigues, S., Pinto, G. A. S., and Fernandes, F. A. N. (2008). “Optimization of ultrasound extraction of phenolic compounds from coconut (Cocos nucifera) shell powder by response surface methodology," Ultrason. Sonochem. 15(1), 95-100.

Rostrup-Nielsen, J. R. (2005). "Making fuels from biomass," Science 308(5727), 1421-1422.

Sarkanen, K. V., Chang, H. M., and Allan, G. G. (1967). "Species variation in lignins. 2. Conifer lignins," Tappi J. 50(12), 583-586.

Scalbert, A., Monties, B., Guittet, E., and Lallemand, J. Y. (1986). "Comparison of wheat straw lignin preparations. I. Chemical and spectroscopic characterizations," Holzforschung 40(2), 119-129.

Smith, D. C. C. (1955). "P-Hydroxybenzoate groups in the lignin of aspen (Populus tremula)," J. Chem. Soc. 2347-2351.

Sun, R. C., Fang, J. M., and Tomkinson, J. (1999). "Fractional isolation and structural characterization of lignins from oil palm trunk and empty fruit bunch fibres," J. Wood Chem. Technol. 19(4), 335-356.

Sun, R. C., Tomkinson, J., Sun, X. F., and Wang, N. J. (2000). "Fractional isolation and physico-chemical characterization of alkali-soluble lignins from fast-growing poplar wood," Polymer 41(23), 8409-8417.

Vanholme, R., Morreel, K., Ralph, J., and Boerjan, W. (2008). "Lignin engineering," Curr. Opin. Plant Biol. 11(3), 278-285.

Villaverde, J. J., Li, J. B., Ek, M., Ligero, P., and de Vega, A. (2009). "Native lignin structure of Miscanthus $x$ giganteus and its changes during acetic and formic acid fractionation," J. Agric. Food Chem. 57(14), 6262-6270.

Wang, J., Sun, B. G., Cao, Y. P., Tian, Y., and Li, X. H. (2008). “Optimisation of ultrasound-assisted extraction of phenolic compounds from wheat bran," Food Chem. 106(2), 804-810.

Weng, J. K., Li, X., Bonawitz, N. D., and Chapple, C. (2008). "Emerging strategies of lignin engineering and degradation for cellulosic biofuel production," Curr. Opin. Biotechnol. 19(2), 166-172.

Yang, H. P., Yan, R., Chen, H. P., Zheng, C. G., Lee, D. H., and Liang, D. T. (2006). "In-depth investigation of biomass pyrolysis based on three major components: hemicellulose, cellulose and lignin," Energ. Fuel. 20(1), 388-393.

Yang, S., Lu, L., and Ni, Y. (2006). "Cloned poplar as a new fibre resource for the Chinese pulp and paper industry," Pulp Pap-Canada 107(2), 34-37.

Yuan, T. Q., He, J., Xu, F., and Sun, R. C. (2009). "Fractionation and physico-chemical analysis of degraded lignins from the black liquor of Eucalyptus pellita KP-AQ pulping," Polym. Degrad. Stab. 94(94), 1142-1150.

Yuan, T. Q., Xu. F., He, J., and Sun, R. C. (2010). "Structural and physico-chemical characterization of hemicelluloses from ultrasound-assisted extractions of partially delignified fast-growing poplar wood through organic solvent and alkaline solutions," Biotechnol. Adv. 28(5), 583-593.

Article submitted: October 4, 2010; Peer review completed: November 20, 2010; Revised version received: November 28, 2010; Accepted: December 12, 2010; Published: December 20, 2010. 